\title{
Force Majeure and Unfulfillment of Construction Contracts due to COVID-19 in Indonesia
}

\author{
Edison Hatoguan Manurung ${ }^{1}$, Ina Heliany ${ }^{2}$ \\ ${ }^{1} 17$ August 1945 University, Jakarta - Indonesia; ${ }^{2}$ Mpu Tantular University, Jakarta - Indonesia \\ E-mail : Edisonmanurung2010@yahoo.com ${ }^{1}$; inaheliany6@gmail.com²
}

\begin{abstract}
The COVID-19 pandemic has a significant impact on economic stability, including a slowdown and even a recession in the world economy. This also has an impact on the construction problem in Indonesia which destroys all social pillars and especially business actors, plus the government has implemented various policies ranging from the relaxation of imports to large-scale social restrictions. This phenomenon hits business actors which have an impact on the difficulty of doing business normally. In fact, many construction projects in a district have been neglected because materials and workers come from neighboring districts whose mobility has been disturbed since the implementation of the regional quarantine policy. This is not to mention exacerbated by the escalation in prices and raw materials that increased due to the increase in the dollar exchange rate and imports. This results in projects not being completed on time. For example, the PLTS development in West and East Bali was delayed by 3-6 months. In addition, the construction of the Delta Park in Dalung Village, North Kuta Sub-District, cannot be continued this year. Meanwhile, in a contractual relationship, each party that has agreed on an agreement is obliged to carry out all the provisions contained in the agreement. This is explained in Law Number 18 of 1999 (Construction Services Law). However, COVID 19 makes one party unable to fulfill obligations. So that they cannot complete what has been promised. In the perspective of civil law, of course, parties who cannot carry out their obligations can be qualified as having "broken their promises" or "negligent in carrying out their obligations". Based on the explanation above, researchers had an interest in conducting research on : 1. Can COVID-19 qualify as force majeure even though it is not stated in the agreement? 2. Can parties who are negligent in carrying out their obligations be released from the responsibility to compensate for losses arising from not implementing an agreement during force majeure due to COVID-19? This study used several stages namely: 1) Problem identification, 2) Literature study, 3) Primary and Secondary Data Collection, 4) Analysis and 5) Reporting. This study used a qualitative method using an approach through the Civil Code and Law Number 2 of 2017 on Construction Services. Based on the results, COVID-19 can be said to be a Force Majeure based on Law Number 24 of 2007 on Disaster Management. It is qualified as force majeure even though it is not regulated in this agreement, this is based on article 57 of Law Number 2 of 2017 concerning construction services which can be interpreted
\end{abstract}

as a force majeure is an event that arises beyond the willing and ability of the parties that cause harm to one party. Then in Law Number 24 of 2007 concerning disaster management and strengthened by a statement from the competent authority and a statement from a legitimate government, namely a statement from the World Health Organization which has stated that COVID-19 is a pandemic. This was also strengthened by Presidential Decree No. 12 of 2020 concerning the designation of COVID-19 as a national disaster. So thus it can be said that the COVID-19 that occurs and spreads can qualify as force majeure, even though it is not regulated in the Agreement, with due regard to its nature and elements, COVID-19 can qualify as force majeure. However, this is not sufficient to become the basis that one of the parties to the agreement can delay the implementation of its obligations. In this case, it is necessary to prove that there is a direct causal relationship between the COVID-19 outbreak along with Government policies in overcoming COVID-19 which results in the inability to carry out obligations in an agreement. If the corona virus outbreak ends or the government removes the lockdown, the service user can demand the fulfillment of achievements again or can also choose to end the agreement with compensation. This is in accordance with the provisions of Article 1267 of the Civil Code.

Keywords : Covid 19, Construction Contract, Force Majeure.

\section{INTRODUCTION}

The COVID-19 pandemic has a significant impact on economic stability, including a slowdown and even a recession in the world economy. This also has an impact on the construction problem in Indonesia which destroys all social pillars and especially business actors, plus the government has implemented various policies ranging from the relaxation of imports to large-scale social restrictions. This phenomenon hits business actors which have an impact on the difficulty of doing business normally.

In fact, many construction projects in a district have been neglected because materials and workers come from neighboring districts whose mobility has been disturbed since the implementation of the regional quarantine policy. This is not to mention exacerbated by the escalation in prices and raw materials that increased due to the increase in the dollar exchange rate and imports. This results in projects not 
being completed on time. For example, the PLTS development in West and East Bali was delayed by 3-6 months [1]. In addition, the construction of the Delta Park in Dalung Village, North Kuta Sub-District, cannot be continued this year [2].

In the perspective of civil law, of course, parties who cannot carry out their obligations can be qualified as having "broken their promises" or "negligent in carrying out their obligations". Meanwhile, the government policy that defines the COVID-19 pandemic as a national disaster should be appreciated, where the focus and seriousness of the government in overcoming this national disaster is increasingly visible by establishing COVID-19 as a type of disease that causes public health emergencies. Therefore, in order to establish the COVID-19 pandemic as a national disaster, the government urges the public to carry out physical distancing and work and learn from home. This government appeal was followed by a number of regulations such as Government Regulation Number 21 of 2020 on Large-Scale Social Restrictions to Accelerate Handling of Corona Virus Disease 2019 (COVID-19), Presidential Decree Number 11 of 2020 on Determination of Public Health Emergencies for Corona Virus Disease 2019, Minister of Health Regulation Number 9 of 2020 on Guidelines for Large-Scale Social Restrictions to Accelerate Handling of Corona Virus Disease 2019 (COVID-19), and Presidential Decree Number 12 of 2020 on Determination of Non-Natural Disasters Spread of Corona Virus Disease 2019 (COVID-19) as a National Disaster [3].

The issuance of the Presidential Decree, Government Regulation in Lieu to Law, and Government Regulation at the same time describes a situation that is very urgent, emergency, and requires fast action to normalize or control the situation. The construction service sector as part of the economic actors has felt a huge impact on the Covid-19 outbreak. Elements of construction work such as materials, workers, equipment, transportation, time, and mobility are very much affected and can cause uncertainty. Meanwhile, in a contractual relationship, each party that has agreed on an agreement is obliged to carry out all the provisions contained in the agreement. This is explained in Law Number 18 of 1999 (Construction Services Law). However, COVID 19 makes one party unable to fulfill obligations. So that they cannot complete what has been promised. In this regard, researchers had an interest in raising issues related to agreements and COVID 19. The issues discussed in this study can be seen in the next section.

\section{PROBLEMS}

1. Can COVID-19 qualify as force majeure even though it is not stated in the agreement?

2. Can parties who are negligent in carrying out their obligations be released from the responsibility to compensate for losses arising from not implementing an agreement during force majeure due to COVID-19?

\section{RESEARCH METHOD}

This study was included in qualitative study. Qualitative studies are descriptive and tend to use analysis. This study used the library research method. This study used secondary data from the primary sources or authorities, secondary sources or authorities, and tertiary sources or authorities. The primary source was from legislation, the secondary source was in the form of books, literature, and scientific works in the field of law, while the tertiary source was from non-legal scientific works such as the RKUHP, encyclopedia, and legal dictionaries.

\section{DISCUSSION}

\section{Covid-19 can qualify as force majeure even though it is not stated in the agreement.}

In an agreement, the force majeure clause is a written general thing.

An event is considered a force majeure event if it occurs unexpectedly, is unexpected [4], and cannot be avoided [5]. There are two common consequences of force majeure, namely project termination and project suspension [6]. If a force majeure event occurs leading to the termination of the project, each party bears its own risk and consequences. In some cases, the contractor may be compensated for the part of the work that was done before the force majeure [7]. Meanwhile, if a project suspension occurs due to a force majeure event, the contractor is usually entitled to an extension of time [8].

Legal relationships that are born through an agreement cannot always carry out the aims and objectives, where this situation can occur due to default whether it is carried out by service providers or service users, where there is coercion, error, fraudulent acts, or force majeure which in Indonesian law is known as "Overmacht". The consequences that arise from this situation cause an agreement (contract) to be canceled. Force majeure is one of the clauses that are usually in an agreement where its position is in a principal agreement, not separated as an additional agreement, and linked to the main agreement as an accesoir agreement [9].

Force Majeur refers to a condition where the event will have a negative impact on the fulfillment of contract obligations [10]. The handling of COVID-19 has had a direct and indirect impact on construction industry companies including disruption of supply chain logistics, delays in work, suspension, termination, and even bankruptcy [11]. Force majeure is one of the clauses that usually exist in an agreement, it is said to be one of the clauses because its position in an agreement is in the main agreement, is not separated as an additional agreement and is linked to the main agreement as an accesoir agreement [12].

Riduan Syahrani explained that force majeure is usually translated as "forceful condition" and some are called "cause force" [13]

"Force majeure is a situation that occurs outside the will of the parties to the contract and cannot be predicted in advance so that the obligations specified in the contract cannot be fulfilled" [14].

Regulations regarding force majeure in Indonesia can be seen in the Civil Code, especially in Article 1244 j.o Article 1245 which states as follows:

Article 1244 of Civil Code "If there is a reason for the debtor to be sentenced to compensate costs, losses, and interest and cannot prove that the thing was not carried out or not at the right time, the agreement was carried out, due 
to an unexpected, even unaccountable thing, all of that too happens when bad faith does not exist ".

Article 1245 of Civil Code: "It is not necessary to compensate costs, losses and interest if due to force majeure [overmacht] or due to an accidental situation, the debtor is unable to provide or do something that is required, or because of the same things has committed an illegal act" [15].

Based on these regulations, the main elements that can cause force majeure are:

1. There are unexpected events;

2. There are obstacles that make an achievement impossible;

3. The inability is not caused by the fault of the debtor;

4. This inability cannot impose a risk on the debtor.

Because of the large possibility of a force majeure, to obtain legal certainty, the parties usually include a clause with a list of events that can become a force majeure in their agreement, such as:

Force Majeure Event means the occurrence of an event

of:

a. Act of God (such as, but not limited to fires, explosions, earthquakes, drought, tidal waves and floods);

b. War, hostilities (whether war be declared or not), invasion, act of foreign enemies, mobilization, requisition, or embargo;

c. Rebellion, revolution, insurrection, or military or usurped power, or civil war;

d. Contamination by radio-activity from any nuclear fuel, or from any nuclear waste from the combustion of nuclear fuel, radio-active toxic explosive, or other hazardous properties of any explosive nuclear assembly or nuclear component of such assembly;

e. Riot, commotion, strikes, go slows, lock outs or disorder, unless solely restricted to employees of the Supplier or of his Subcontractors;

f. Acts or threats of terrorism; or

g. Other unforeseeable circumstances beyond the control of the Parties against which it would have been unreasonable for the affected party to take precautions an which the affected party cannot avoid event by using best efforts [16].

Force majeure is a legal concept derived from Roman law (vis motor cui resisti non potest) which is adopted in various legal systems. Doctrine in common law interprets this word as an inability to perform an achievement on a contract, which is analogous to but not identical with force majeure [17]. Mochtar Kusumaatmadja stated that force majeure or vis major can be accepted as an excuse for not fulfilling the obligation due to the loss of the main objective of the agreement. This is aimed at physical and legal implementation, not only due to difficulties in carrying out obligations. Mieke Komar Kantaatmadja explained that [18]:

1. There are no changes to the agreement formulation.

2. The change concerns a condition which is fundamental to the agreement.

3. These changes cannot be predicted in advance by the parties.

4. The result of these changes must be radical, thus changing the scope of the obligations that must be carried out according to the agreement.
5. The use of this principle cannot be applied to border agreements and also changes due to violations committed by the party filing the claim.

The force majeure clause in a contract is intended to prevent loss of a party to an agreement due to an act of God, such as fire, earthquake floods, rainstorms, hurricanes, (or other natural disasters), power outages, catalyst damage, sabotage, war, invasion, civil war, rebellion, revolution, military coup, terrorism, nationalization, blockade, embargo, labor disputes, strikes, and sanctions against a government [19]. Etymologically, this term comes from French which means "greater power" [20]. In the context of civil law, force majeure is a condition in which a person cannot carry out an obligation not because of intentionally or negligently, but because there are things that are beyond their control and are very influential in not carrying out obligations (overmacht). Their minds are focused on natural disasters or accidents that are beyond human ability to avoid, making it impossible to keep promises. For example, the promised object has been destroyed. This view has begun to recede with the argument that force majeure can be relative so that the obligations imposed can be carried out through other means [21].

The relativity of the overmacht had been explored by Abdulkadir Muhammad as follows:

1. A situation that cannot fulfill the achievement due to an event that destroys the object of the agreement. This situation shows the absolute nature of force majeure.

2. A situation that indicates that the achievement cannot be fulfilled due to an event that can prevent the actions of the debtor from fulfilling the achievement. This situation can be absolute or relative.

3. A situation that shows uncertainty because it cannot be known or expected to occur when entering into an agreement by both the debtor and creditor. This situation shows that the fault is not on both parties, especially the debtor [22].

Furthermore, force majeure must meet certain elements which can be seen in the Supreme Court Decision No.409K/Sip/1983 dated 25 October 1984 in the case between Rudy Suardana and the local shipping company PT Gloria Kaltim, which in essence, the Panel of Judges stated that force majeure must meet the following elements:

1. Unexpected;

2. It cannot be prevented by parties that must fulfill obligations or carry out agreements; and

3. Beyond the fault of the party.

In simple terms, force majeure is synonymous with natural events (act of God) which causes a person to be unable to carry out their obligations due to disasters. However, in its development, force majeure is also interpreted broadly, this can be seen in the decision of the Supreme Court No. 3389K/Pdt/1984 where the administrative action of a legitimate ruler in the sense of a sudden government policy that cannot be predicted by the parties can also qualify as force majeure.

Thus, force majeure is a condition in which one of the parties is unable to carry out an obligation, not because of intention or intent but there are events that are unable to carry out that obligation. If examined, force majeure has the same implication, namely the inability of either party to carry out obligations. So that the juridical implication of not 
carrying out an obligation, the injured party can ask for compensation as a result of not carrying out the obligation by one of the parties.

Because in the field of construction services there is no definition of force majeure, however, the Law only requires that each construction work contract must include a description of force majeure as specified in Article 47 paragraph (1) letter $\mathrm{j}$ of Law 2/2017 which shows: "force majeure contains provisions concerning events that occur beyond the willingness and ability of the parties which cause harm to one of the parties".

According to the provisions of this article and its explanation, force majeure is defined as an event that occurs beyond the willingness and ability of the parties which causes a loss to one of the parties. Force majeure includes:

1. Absolute force majeure where the parties may not exercise their rights and obligations; and

2. Relative force majeure where the parties are still allowed to exercise their rights and obligations. The parties can agree on the risks caused by coercive circumstances through insurance institutions.

With regard to the construction agreement in Article 23 paragraph (1) letter j Government Regulation Number 29 of 2000 on Implementation of Construction Services also states that: "the force majeure clause in the construction work contract includes an agreement regarding special risks, various types of force majeure, and rights and obligations of service users and service providers to force majeure " [23].

Whereas in Article 57 Law Number 2 of 2017 on Construction Services, it can be interpreted that force majeure arises beyond the willingness and ability of the parties which causes a loss to one of the parties [24].

Regarding the non-regulation of COVID-19 in the force majeure clause, it can be reviewed first through the provisions of the applicable laws. Based on Article 1 paragraph (3) Law Number 24 of 2007 on Disaster Management ("Disaster Management Law") states that:

"Non-natural disasters are disasters caused by nonnatural events or series of events, including technological failure, modernization failure, epidemics, and disease outbreaks."

In the Disaster Management Law, epidemics and disease outbreaks can qualify as non-natural disasters caused by a series of non-natural events. But is this definition sufficient to qualify COVID-19 as a non-natural disaster? This requires a statement from the agency or party that has the authority to declare that COVID-19 is an epidemic or an outbreak. So, in this case, it is very relevant to use a statement from the World Health Organization which has stated that COVID-19 is a pandemic. This is also strengthened by the Presidential Decree Number 12 of 2020 on the determination of COVID-19 as a national disaster.

It should be noted that there are differences in definitions between plague, epidemic, and pandemic. (1) Plague is a disease that is spread but can still be anticipated. (2) An epidemic is a disease that is spread in large numbers and spread over a geographic area. (3) A pandemic is a disease with an international spread.

Thus, COVID-19 is a non-natural disaster. But this cannot yet affirm that COVID-19 which is a non-natural disaster can qualify as force majeure.
The last point that is important to know in the elements of force majeure is that this epidemic is unwanted, where this outbreak can hinder one of the parties from carrying out their obligations and there is no element of intent or negligence that makes one party unable to carry out obligations. So that it can be said that the COVID-19 that occurs and spreads can qualify as force majeure. So, even though it is not regulated in the agreement, by taking into account the nature and elements of COVID-19 it can qualify as a force majeure.

1. In force majeure due to Covid -19 , parties that are negligent in carrying out their obligations cannot be released from their responsibility to compensate for losses arising from non-performance of an agreement In general, to get answers related to force majeure ecause of Covid 19, force majeure is basically divided into

a. Absolute force majeure; and

b. Relative force majeure [25].

Mariam Darus Badrulzaman stated that absolute force majeure occurs when the obligation really cannot be carried out completely, for example when objects are destroyed due to natural disasters. In this case, the fulfillment of the achievement is not possible for anyone or everyone, while relative force majeure occurs when an agreement is still possible to implement but with very large sacrifices or costs from the debtor, for example, the price of imported raw materials becomes very high or the government suddenly prohibits treaty objects from leaving a port [26].

According to Asser, there are two possible consequences of force majeure, namely termination of the agreement or suspension of obligations [27]. Termination of the agreement occurs when the obstacle is permanent. With the termination of the agreement, the counter-achievement also ends. Meanwhile, a suspension of obligation occurs when the force majeure event is temporary. If the condition of the obstacle has recovered, for example, the export ban is lifted again, then the obligation of the seller will recover to hand over the exported goods.

Mariam Darus Badrulzaman stated that the debtor can state the reasons for force majeure that meet three requirements [28] :

1. The debtor must prove his innocence;

2. The debtor cannot fulfill the obligation in any other way; and

3. The debtor does not bear the risk, either according to the provisions of law or agreement or in good faith must bear the risk.

Apart from paying attention to this, several things must also be considered, namely:

1. If the agreement clearly states that an outbreak or lockdown is a force majeure event, then the corona virus outbreak and lockdown by the government can be used as reasons for force majeure..

If there is no or there is a clause stating "other events beyond the ability of the debtor" or the like, then:

2. Whether it is stated explicitly or not explicitly in the agreement, what must be considered is the achievement, not just the event and the event is an unexpected event before the agreement was made.

If his achievement is in the form of an obligation to do something that is personal (cannot be replaced by other people), for example singing in a concert, the singer can be 
exempted from carrying out the obligations as promised by reason of the pandemic. This is in line with a statement by Asser that if it is dangerous to life, the possibility of life, health, honor, and independence, the reasons for force majeure can be put forward as an obstacle to carrying out obligations [29]. The implementation of the obligation to provide construction services that could endanger the survival and health can be postponed by reason of this compelling situation. Then, the occurrence of the coronavirus outbreak must also be an unexpected event at the time the agreement is made. This means that if there is an agreement made when the outbreak is spreading and infecting, the outbreak and lockdown event cannot be used as an excuse as a force majeure.

3. If the force majeure is temporary, then it only postpones the obligations of the debtor and does not terminate the agreement unless stated in the agreement or there is an agreement of the parties.

Thus, if the coronavirus outbreak ends or the government removes the lockdown, the service user can demand the fulfillment of achievements again or can also choose to end the agreement with compensation. This is in accordance with the provisions of Article 1267 of the Civil Code which states: Parties to whom the achievement is not fulfilled then can choose; forcing the other party to comply with the agreement, if it is still feasible, or demanding the cancellation of the agreement with reimbursement of costs, losses, and interest. For example, in the case of construction agreements, due to the coronavirus outbreak, the parties (providers and users of construction services) by mutual agreement can reschedule the provision of construction services.

\section{CONCLUSION}

COVID-19 which has been designated by the government as a national disaster can qualify as force majeure even though it is not regulated in the agreement. However, this is not sufficient to serve as the basis that one of the parties to the agreement can suspend the implementation of its obligations. In this case, it is necessary to prove that there is a direct causal relationship between the COVID-19 outbreak along with Government policies in overcoming COVID-19 which results in the inability to carry out obligations in an agreement. The coronavirus outbreak ends or the government revokes the lockdown, service users can demand the fulfillment of achievements again or can choose to end the agreement with compensation. This is in accordance with the provisions of Article 1267 of the Civil Code.

\section{RECOMMENDATION}

In force majeure, the thing that needs to be put forward is the wisdom of the parties in responding to this condition. Each party must realize wisely that there are other things that can be put forward such as jointly bearing losses for losses suffered by one of the parties or if the force majeure prevents one party from carrying out its obligations so that the other party can compensate the counterpart in order to carry out its obligations at another mutually agreed time.

\section{REFERENCES}

[1] Yanita Petriella, "Waduh! Proyek PLTS Ikut Terhenti karena Virus Corona", Retrifed Agustus 12 2020, [Online] from https://ekonomi.bisnis.com/read/20200421/44/123031 4/waduh-proyek-plts-ikut-terhenti-karena-virus-corona

[2] NV. "Dampak Covid-19 Proyek Taman Delta Terhenti", Retrifed Agust 12 ,2020, [Online] from https://www.nusabali.com/berita/74023/dampakcovid-19-proyek-taman-delta-terhenti

[3] Desi Syamsiah, "Penyelesaian Perjanjian Hutang Piutang Sebagai Akibat Forje Majeur Karena Pandemic Covid 19”, Legal Standing Jurnal Ilmu Hukum, Vol.4 No. 1, Maret 2020. Retrifed Agust 10, 2020. [Online] from http://journal.umpo.ac.id/index.php/LS/article/view/27 83

[4] Azfar, F, "The Force Majeure "Excuse"', Arab Law Quarterly, Vol. 26, No. 2, p 249- 253, 2012.

[5] Ezeldin, A. S., and Helw, A. A. "Proposed Force Majeure Clause for Construction Contracts under Civil and Common Laws". Journal of Legal Affairs and Dispute Resolution in Engineering and Construction, Vol. 10, No. 3, 2018.

[6] Hagedoorn, J., and Hesen, G, "Contract law and the governance of inter-firm technology partnerships: An analysis of different modes of partnering and their contractual implications:", Journal of Management Studies, Vol. 44, No. 3, p 342-366, 2007.

[7] Hagedoorn, J., and Hesen, G. "Contract law and the governance of inter-firm technology partnerships: An analysis of different modes of partnering and their contractual implications". Journal of Management Studies, Vol. 44, No. 3, 342-366, 2007.

[8] Seng Hansen, "Does the COVID-19 Outbreak Constitute a Force Majeure Event? A Pandemic Impact on Construction Contracts". Journal of Civil Engineering Forum, Vol. 6, No 2. P 201-214. 2020. [Online] Retrifed from https://journal.ugm.ac.id/jcef/article/view/54997/2768 6

[9] Elly Erawati \& Herlien Budiono, Penjelasan Hukum Tentang Kebatalan Perjanjian, Nasional Legal Reform Program, Jakarta : Gramedia, 2010.

[10] Bleby, M., "Construction feels COVID-19 delays in supply chain”. 2020, [Online] Retrifed from :https://www.afr.com/ property/commercial/construction-feels-covid-19delays-in- supply-chain-20200304- p546pv.R

[11] Johnson, N., Moore, R., and Mitha, Y., "Is COVID-19 likely to be a valid basis for avoidingcontractual obligations?", 2020. [Online] Retrifed from https://www.herbertsmithfreehills.com/latestthinking/i s-covid-19-likely-to-be-a-valid-basisfor-avoidingcontractual-obligations .

[12] Agri Chairunisa Isradjuningtias, "Force Majeur (Overmacht) Dalam Hukum Kontrak (Perjanjian ) Indonesia”. Jurnal Veritas Et Justitia, Vol. 1 No.1, 2015. [Online] Retrifed August 9,2020, from http://journal.unpar.ac.id/index.php/veritas/article/vie $\mathrm{w} / 1420$ 
[13] Riduan Syahrani, "Seluk Beluk dan Asas-asas Hukum Perdata". Bandung: Alumni. 243 \& 154. 2006.

[14] Peraturan Pemerintah Nomor 16 Tahun 2018 Tentang Pengadaan Barang dan Jasa Pemerintah . Pasal 1 ayat (52).

[15] Kitab Undang-Undang Hukum Perdata.

[16] Tri Harnowo, "Wabah Corona sebagai Alasan Force Majeur dalam Perjanjian”. August 7, 2020. [Online] Retrifed,

from https://www.hukumonline.com/klinik/detail/ulasan/lt5 e81ae9a6fc45/wabah-corona-sebagai-alasan-iforcemajeur-i-dalam-perjanjian/

[17] Anonim, "Force Majeure in Troubled Times: The Example of Libya", Jones Day Publication, Houston, pg. 1.

[18] Harry Purwanto, "Keberadaan Asas Rebus Sic Stantibus Dalam Perjanjian Internasional", Jurnal Mimbar Hukum Edisi Khusus. 115. 2011.

[19] Thomas S. Bishoff and Jeffrey R. Miller. "Force Majeure and Commercial Impractiability: Issues to Consider Before the Next Hurricane or Matural Disaster Hits", The Michigan Business Law Journal, Vol. 1, No. 1, pg. 17, 2009.

[20] Irma Devita, "Dapatkah Covid-19 Dianggap Peristiwa Force Majeur Dalam Kontrak". August 7, 2020, [Online] Retrifed from https://irmadevita.com/2020/dapatkah-covid-19dianggap-peristiwa-force-majeure-dalam-kontrak/

[21] Subekti, "Hukum Perjanjian. Jakata:Intermasa. Jakarta". 56. Lihat Achmad Ihsan. 1969. Hukum Perdata I B. Jakarta : Pembimbing Masa. 41, 1987.

[22] Abdulkadir Muhammad, Hukum Perikatan, Bandung : Citra Aditya Bakti, 1992.

[23] Peraturan Pemerintah Nomor 29 Tahun 2000 tentang Penyelenggaran Jasa Konstruksi sebagaimana yang telah diubah pertama kali dengan Peraturan Pemerintah Nomor 59 Tahun 2010 tentang Perubahan atas Peraturan Pemerintah Nomor 29 Tahun 2000 tentang Penyelenggaraan Jasa Konstruksi

[24] Undang-Undang Nomor 2 Tahun 2017 tentang Jasa Konstruksi;

[25] Subekti. Pokok-pokok Hukum Perdata, Jakarta: PT. Intermasa. 2002.

[26] Mariam Darus Badrulzaman, KUH Perdata Buku III: Hukum Perikatan dengan Penjelasan. Bandung: Alumni, 1969.

[27] Asser, Pengajian Hukum Perdata Belanda. Jakarta: Dian Rakyat. 1991.

[28] Mariam Darus Badrulzaman, KUH Perdata Buku III: Hukum Perikatan dengan Penjelasan, Bandung: Alumni, 1996.

[29] Asser, Pengajian Hukum Perdata Belanda. Jakarta: Dian Rakyat. 1991. 